\title{
Can standards save organic farming from conventionalisation? Dynamics of project and rules in a French organic producers' organisation
}

\section{To cite this article}

Dufeu I., Le Velly R., Bréchet J.P., Loconto A. (2020), Can standards save organic farming from conventionalisation? Dynamics of collective projects and rules in a French organic producers' organization, Sociologia Ruralis, 60 (3), pp 621-638 (doi: 10.1111/soru.12298)

\section{Ivan Dufeu*}

*Corresponding author

University of Angers, Laboratoire GRANEM, EA 7456, IUT d'Angers, 4 Boulevard de Lavoisier, 49000 Angers, France. Professor, Tel : 33(0)676 0870 28/ 0244688880. ivan.dufeu@univ-angers.fr

\section{Ronan Le Velly}

UMR Innovation, Univ. Montpellier, Cirad, Inrae, Montpellier SupAgro, France. Professor. levelly@supagro.fr

\section{Jean-Pierre Bréchet}

University of Nantes, Laboratoire LEMNA, EA 4272. Institut d'Administration des Entreprises, France.Professor. jean-pierre.brechet@univ-nantes.fr

\section{$\underline{\text { Allison Loconto }}$}

Laboratoire Interdisciplinaire Sciences Innovations Sociétés (LISIS), UMR ESIEE Paris INRAE - UPEM No1236 / FRE CNRS No3705, France. Doctor. allisonmarie.loconto@inrae.fr

Keywords: conventionalisation, standardisation, certification, rules, collective action, organic agriculture.

\section{Acknowledgements}

The authors gratefully acknowledge all BLO members, for the hundreds of hours they gave us and for the doors they opened for us, and our colleague Laurent Le Grel for empirical work.

The authors thank also the editor Dr. Bettina Bock and the anonymous reviewers for their useful advice on an earlier version of this paper. 


\title{
Can standards save organic farming from conventionalisation? Dynamics of collective projects and rules in a French organic producers' organisation
}

\begin{abstract}
The unintended consequences of standards and certification schemes, particularly their challenges for alternative agri-food networks, is a core concern of rural sociology. The conventionalisation of organic agriculture is a prime example. In this article, we contribute to this debate by studying standards that organic farmers developed for themselves within a French organic producers' organisation. We introduce a "regulationist theory of collective action" and show that these farmers crafted specific rules that go beyond the EU regulation, which in turn gave life to their own alternative, collective project. We thus demonstrate that standardisation and certification do not inevitably engender conventionalisation.
\end{abstract}

\section{Introduction}

The development of auditable standards and third-party certification schemes that began in the 1980s has regularly been analysed as a way of closing the gap between organic and conventional agricultural practices (e.g., Fouilleux and Loconto 2017). Often, these academic debates about closing the gap equate conventionalisation with the standardisation effects of formal standards and certification schemes (Darnhofer 2020; Arcuri 2015). For example, Guthman's pathbreaking work on organic agriculture identified myriad causes to explain how the alterity of organic farming in California was weakened in the 1990s; however, she deliberately highlighted the codification of practices in production and processing standards as fundamental to the conventionalisation of organic (Guthman 2004a; Guthman 1998). This line of research 
generally presents two streams of critique: 1) the content of the rules set in the standards and 2) the effects of standardisation and certification.

First, the rules set in standards were deemed to be narrowly defined and too permissive. Studies found that the agro-ecological principles that gave rise to organic agriculture were often diluted, especially those asserted by IFOAM, during the process of translation into public standards (Padel et al. 2009; Seufert et al. 2017). For example, researchers pointed to the lack of consideration for farm workers' rights or the authorisation of inputs with controversial health or environmental impacts (Guthman 1998). Several explanations for this dilution were put forward. Some authors stressed how difficult it was in practice to maintain the complexity of certain agro-ecological principles when it was necessary to write specific rules, the enforcement of which had to be "objectively" verifiable (Seppänen and Helenius 2004). Indeed, the act of codifying standards resulted in stating general rules, which was contrary to the logic of adapting to local situations promoted by the pioneers of organic farming (Vogt et al. 2005). Other authors stressed the pressure exerted by conventional agriculture actors, together with opportunistic actors in organic farming circles, which resulted in the adoption of criteria favourable to quick farm conversion and market development (Guthman 2004a). The history of these processes is filled with conflict among actors who sought more or less strict standards (Vos 2000; DuPuis and Gillon 2009). Often, the advocates for laxity prevailed (Jaffee and Howard 2010), particularly in the context of international harmonisation and competition with other “sustainability” standards (Mutersbaugh 2005; Loconto and Fouilleux 2014).

Second, scholars argued that the standardisation brought about through certification schemes had perverse effects. Following directly from the question of standards' lax content, they stated that this opened the door to entry by actors engaged in industrial organic agriculture (Darnhofer et al. 2010). The public standards allow, for example, conversion to organic farming by simply replacing synthetic inputs with organic ones. This is much easier than conversion to 
agro-ecological production, which requires far-reaching reconfigurations of the agro-ecosystem (Rosset and Altieri 1997). An alarmist scenario foresaw the disappearance of the most militant and diversified farms in the medium term due to high production costs (Allen and Kovach 2000; Guthman 2004b). Moreover, researchers claimed that the complexity and costs of certification were obstacles to the entry of economically marginalised farmers. Standardisation thus favoured the most economically and technically robust organisations (Gómez Tovar et al. 2005; Jaffee 2007). Based on in-depth case studies, another group of critical studies stressed that standards degraded personalised relations and instigated a shift from a system of partnership and dialogue to one of surveillance and inspection (Getz and Shreck 2006; Dolan 2010; Hatanaka 2014). Labels were also accused of "re-fetishizing" (Eden et al. 2008, p. 1044). That is, when the organic label hides the diversity of practices, consumers no longer see that not all organic products are equivalent (Daviron and Vagneron 2011). In this way, standards and thirdparty certification incite a passive, depoliticised form of sustainable consumption in which consumers place their trust in labels rather than questioning how agri-food networks operate (Dubuisson-Quellier and Lamine 2008).

Two important lessons can be drawn from this literature. First, written rules are important for collective action. Far from being a simple codification of what exists in practice, these rules act upon the world (Busch 2011). Second, this body of literature tends to promote another model of organic agriculture that is founded on direct sales and participatory guarantee schemes (Nelson et al. 2010). In these "post-organic" models (Goodman et al. 2012), the rules are deliberately fuzzier and open to negotiation (Teil 2014). The purpose is to adapt to local contexts and foster learning; it is offered up as the only true way to maintain organic alterity. However, more recently, empirical evidence suggests that the relationship between standards and standardisation is not so straightforward (Brunsson, Rasche and Seidl 2012; Loconto and Demortain 2017; Timmermans and Epstein 2010). In this article we, therefore, aim to answer 
the question if formal standardisation and certification processes must always give rise to conventionalisation, or if there are exceptions to this rule?

This research question deserves attention because its response will offer a more nuanced, less deterministic, picture of organic standards and their effects (Lockie and Halpin 2005; Gibbon 2008; Campbell and Rosin 2011; Lehtimäki 2019; Darnhofer 2020). This will help to push our analysis beyond the standardisation/conventionalisation binary and postorganic models. We, therefore, present the results of five years of participatory research in an organic fruit and vegetable producers' organisation in western France called Bio Loire Océan $(B L O)$. We demonstrate that these producers decided to establish a private standard and thirdparty certification with the objective of pursuing a vision of organic agriculture that is stricter than that of the European Union (EU) regulation. We argue that drawing up formal rules enabled the actors to realise their own collective project, defined by the members themselves, and thereby circumventing the standardisation tendencies of certification schemes.

The article proceeds as follows: We begin by introducing our case and research method. We then present our conceptual framework, centred on the concepts of "rules", "projects" and "collective action", and inspired by the French school of organisational sociology (Crozier and Friedberg 1980; Friedberg, 1997; Reynaud 1997), American pragmatist philosophy (e.g., Dewey 1929) and some of its contemporary variants (Joas 1996; Emirbayer and Mische 1998). We then explain how BLO actors self-regulated their behaviour through written documents and technical and administrative devices that enabled them to maintain a dynamic, unconventional collective project. We then discuss how rules aimed at setting verifiable standards combined 
with third-party certification can also provide resistance to the conventionalisation of organic agriculture if it includes a dynamic, continuous process of collective learning.

\title{
Case study background and methodology
}

\author{
Bio Loire Océan (BLO)
}

BLO is an association of organic fruit and vegetable growers in the Pays de la Loire, in western France. It currently has seventy members who account for close to a quarter of the total organic fruit and vegetable production in the region. It was created in 1997 by a "nucleus of farmers who said that, together, they would be stronger in dealing with buyers" (interview with a vegetable farmer and BLO member in 2016). Since then, the association has gradually expanded, with an average increase of two new members per year, in order to aggregate a significant supply for large buyers, to organise the production of farmers' seeds, and to institute an organic box subscription scheme. The association is run by five employees. Its financial resources come from membership fees, commercial activities, and public and private subsidies. Membership fees are set at 2-3 per cent of turnover, depending on the type of work done with the association, plus an annual flat fee of $€ 40$. In 2018, BLO's turnover surpassed $€ 4$ million.

The Biocoop network - the largest network of stores specialised in organic produce in France, and a key actor in the creation of BLO - accounts for close to 72 per cent of its market. The rest of the sales comes mostly (17 per cent) from Les Paniers Bio Solidaires. The latter is an organic fruit and vegetable box-scheme that was developed in partnership with social integration enterprises and had 2,700 subscribers in 2018. On average, 20 per cent of the members' output is sold via BLO. This means that the farmers have also diversified their marketing channels beyond the association. In addition, 10 per cent of the members do not market their produce through the association. Some members have joined BLO to participate in their sponsored activities, like the farmers' seed network. Others "come above all for the 
exchanges with their colleagues" (interview with the coordinator of the association, 2014). The associations' members thus have a diversity of motivations for joining, but they all state that the economic development of an organic agriculture that respects demanding labour and environmental principles remains the overriding goal.

\section{Methods}

The qualitative data used in this article (content analysis) were collected between 2013 and 2018 and consist of the following:

- Participant observation notes during 15 BLO meetings (i.e., general meetings, board meetings, working sessions, etc.), lunches with BLO members and farm visits.

- Field notes of informal exchanges over the 5 years with BLO actors and other actors in the organic commodity chains.

- All of the association's archives and documents since its creation in 1997. We carefully read several thousand pages of archived materials, which enabled us to check (and sometimes to flesh out) interviewees' remarks.

- Twelve semi-structured interviews with BLO members about their professional experiences and those within the association. Seventeen hours of interview data were recorded and transcribed. They are the basis for the quotations used in this article. The transcribed quotations were validated by the interviewees. We then conducted discourse analysis to identify recurring themes, coding them in line with our theoretical framework (i.e., 
characteristics of rules and projects). Finally, we produced timelines so to identify changes in the rules and the project over time.

\section{A regulationist theory of collective action}

Our theoretical framework is centred on the concepts of "collective action", "rules" and “collective projects". We call it "perspective régulationniste en matière de théorie de l'action collective" (BLINDED FOR PEER REVIEW) in French, which could be understood as "a regulationist theory of collective action" in English.

Our entry point is a well-known conceptual puzzle: how is collective action constituted? We treat collective action more broadly than simply the activities of trade unions or social movements. For example, manufacturing in a factory, managing a natural resource, and selling merchandise are all collective actions. They are activities that require the coordination of multiple people and activities. Such collective action is always problematic and research is required to understand what makes it possible (Olson 1965, Ostrom 1990). By examining how two theory-derived notions - rules and collective projects - work in practice, we contribute to solving this conceptual puzzle.

\section{Rules}

The writing of rules is the first step in the constitutional process of collective action. The American pragmatist tradition (Dewey 1929), French organisational sociology (Crozier and Friedberg 1980; Friedberg, 1997; Reynaud 1997) and institutionalist approaches in sociology and economics (Powell and DiMaggio 1991; Ostrom 1994) all recognise that collective action is made possible by the presence of rules that establish what people should and should not do. Whilst rules constrain action, they can also be a resource for action. By rendering the actions of others more predictable, rules orient individual actions towards behaviours that are compatible with collective action. This is not to say that rules have absolute coercive power. 
Actors can continue to develop strategies that serve their own interests and exhibit opportunism (Crozier and Friedberg 1980) within the boundaries of collective rules. Collective action can thus tolerate bargaining, exceptions, and even certain forms of deviance that can carry the seeds of innovation. In a nutshell, social order is always a negotiated order (Strauss et al. 1963).

\section{Collective projects}

A "collective project, understood as a "fuzzy operative expectation of a desired future" (Boutinet 2012), accounts for the human capacity to "imagine a future that they deem desirable and conceive of its broad characteristics" (Le Velly 2019, p. 10). When the project is that of a collective of actors, as in the case of BLO, this concept is useful for understanding why and how the actors organise their behaviour as they do, in anticipation of the collective action that they want to carry out together (Desreumaux and Bréchet 2018).

Two arguments may be made for using the notion of project together with that of rules. First, Emirbayer and Mische (1998) highlight the "projective dimension of agency" in their reading of projects. Put differently, it is the capacity of humans to project, or imagine, future states of the world that are not yet existent, but deemed to be desirable. This concept of project is necessary for understanding situations in which actors debate about the evolution of the rules of their collective action. This enables us to understand their capacity to evaluate the present situation, but also their capacity to imagine other possible means of collective action for the future. This notion of project is particularly relevant for studying alternative agri-food networks, whose actors indeed develop visions for a better organisation of farming and food (Le Velly 2019).

Second, we argue that there is an interdependent relationship between rules and projects: rules without a projective vision do not hold any meaning and a project without rules does not exist in action. A collective project does not belong only to the sphere of ideas, but is embodied through rules and implemented in the physical world through action. Projects are thus not only 
utopian imaginaries, but are instead real utopias (Stock et al, 2015; Wright 2010). Likewise, rules do not lead mechanically to action. They need to be interpreted before being applied; they are "lived rules" (BLINDED FOR PEER REVIEW). The existence of a collective project, even if its content is relatively fuzzy (Le Velly 2019), enables the understanding and legitimacy of the rules. By giving life to the rules-in-use, actors give life to their project. In this way, a collective project is a community of "lived rules" that determine the community's ability to act together.

Our regulationist theory of collective action can be better understood in dialogue with Ostrom's concept of self-regulation (Ostrom 1990, Ostrom et al. 1994). Ostrom calls attention to the ability of communities of natural resource users to set the rules that determine their access to these resources autonomously. She points at the actors' great creativity and the great diversity of rules created in various physical and socio-economic contexts. She underlines that the enforcement of these rules is always subject to how the actors interpret them and use technical and administrative devices. In sum, her work reinforces the importance placed on the role of rules in the tricky formation of collective action. With the examination of the BLO case, we intend to extend the applicability of such a framework to demonstrate that setting rules within a collective project can help to build more desirable forms of agri-food networks (see also Lamine and Rouchier 2016). We do this by examining the written documents (i.e., a charter, standards and specifications) and technical and administrative devices (e.g., a production and orders planning tool) that have been used to develop BLO's farmers collective project over a ten-year period.

\section{BLO's farmers worked out rules and devices to reassert their collective project}

In this section we shall describe the rules and devices that the farmers put into place between 2005 and 2015 to give life to their project. This empirical description demonstrates the changes 
that occurred in the rules and project whilst underlining the fact that these changes were also the results of negotiation and collective learning.

\section{How BLO's specifications were set (2005)}

During the creation of the association, the drafting of BLO's articles of association defined a relatively cursory collective project, “(...) promoting the development of organic fruit and vegetables in the Loire region and representing organic farmers in administrative and trade bodies". This initial statement justifying the creation of the growers' collective in 1997 was then expanded several times in other written documents.

In 2005, the general meeting decided to set up the "BLO's specifications". The farmers first drafted a technical document in which they set some rules, such as "not permitting heated greenhouses" and "cytoplasmic male sterility (CMS)" varieties (technically close to GMOs but allowed by EU organic standards). They then began working on the standardisation of packaging and produce.

"In the beginning, each of us brought our crates of leeks and we had discussions about what kind of leek we wanted for our association, what weight, and how long the white part should be. These discussions and exchanges were a necessary passage for shipping; a clear standard was required" (interview with a vegetable grower and BLO board member).

More general agronomic and environmental conservation principles, which were also included in many private labels, such as those of Nature \& Progrès in France and Demeter (biodynamics), were discussed and introduced. Finally, the introduction of labour criteria (decently paid salaried workers, working conditions), market criteria (fair prices), and social criteria 
(preferring short supply chains) completed the vision of the principles that the collective wanted to apply in their rules.

In this initial version, the text of the "specifications" document was rather general and some of the principles stated in it had no operational translations. Its importance, however, was well understood within the association. For BLO's farmers and management, crafting these rules provided a means to continuously affirm their common project and implement it simultaneously. The discussions that led to their writing engendered a desire to converge towards similar behaviours and inspired a feeling of increased cohesiveness amongst BLO's members. Following their codification, these specifications have been used as a guide to assess new members' applications.

Up until 2013, these specifications remained in document form meant for internal use only. There were no formal inspections. Nevertheless, they served as benchmarks for designing and orienting the collective action throughout this first period. The idea of formalising the rules emerged only later on through new interaction with external stakeholders, for example, with buyers like Biocoop and with researchers (including the authors of this article).

\section{The affirmation of the charter (2013)}

At the general meeting of February 2013, the members decided to rework their founding texts and to draft more specific standards that would be compatible with third-party certification. A first version of a document presented to actors as the BLO charter was written in the spring of 2013. It set a general framework and asserted the commitments to the values and purposes shared by the BLO collective. It was conceived of and written to state what united the members. Thus, it defined the boundaries of the association's project and articulated its uniqueness. The preamble asserts that the aim of the BLO project is the "supportive production of organic fruits and vegetables consistent with sustainability, in tune with local conditions and society's expectations, and respectful of the commodity chain's actors". This charter lists four types of 
values that are important for the association: ecological, economic, labour, and societal values (see Box 1).

\section{Box 1. The Bio Loire Océan charter}

We cite below key excerpts from the charter. The charter affirms four chief values:

"Amongst the ecological values, the BLO producers' goals are the following: to preserve the soil and improve its fertility; to refuse genetic manipulations affecting the integrity of living things (GMOs, CMS, cellular fusion); to act in favour of the development of cultivated and wild biodiversity; and to recycle and limit waste."

"The economic values sought must allow consistent and sustainable development of the value chain with respect for the labour involved and a fair, appropriate price: respect for economic fairness amongst all the actors; contractualisation and planning of crops; gradual and realistic conversion in tune with the markets; and price-setting that must result from consultation and allow the fair remuneration of labour and perpetuation of production plant."

The "social values" concern the life of the collective and employment conditions on the farms: "collective governance and shared values; promoting exchanges and the expression of opinions between members...; partnerships are set up with job market integration structures to boost local employment; limiting job insecurity...promoting and recognising the work done by women."

The societal values express the need for ties and "relations with the territory whilst respecting the commodity chain. Organic agriculture goes beyond growing organic fruits and vegetables without pesticides; it makes it possible to respond to societal issues. The societal values and objectives of BLO are the following: bringing the farmer closer to the consumer; making organic food accessible to the largest number by setting a fair price, multiplying the access 
networks, and reducing the number of middlemen; and maintaining a local employment fabric." (Bio Loire Océan, La Charte, 2013)

Once the charter existed, even as a working document, it was expected to guide the development of private standards that aimed to surpass the "organicness" of the EU Regulation on Organic Agriculture.

\section{The choice of demanding private standards (2014-2015)}

An internal working group was set up to draft the standards, a task that was carried out from 2014 to 2015. A series of working meetings of the farmers, sometimes along with representatives of accredited inspection bodies, researchers, and the drafters of other private specifications (such as Biobreizh, a comparable initiative in the neighbouring Brittany region) was conducted. They were inspired in particular by the standards of: 1) Nature \& Progrès, a French pioneer in organic agriculture and an adamant opponent of the public standard since its creation (Arcuri 2015; Teil 2014); and 2) Bio Cohérence, an organisation created by several organic farmer trade unions across France in 2010 in reaction to the harmonisation of the EU standards. They also turned to the standards set forth by their main customer, the network of Biocoop shops, notably because BLO must comply with Biocoop's supplier requirements. For example, Biocoop recently refused to use plastic film on fruit and vegetable crates and BLO had to incorporate this specification into its own rules. This suggests that self-regulation can sometimes be externally inspired; however, it also means that each newly suggested criterion must be discussed in the context of BLO's own collective project.

The association's bodies validated a first version of the new specifications based on a proposal made during the general meeting in March 2014. This new version, which now complemented the charter, consisted of ten chapters. BLO's standards were aimed at operationalising the 
general principles stated in the charter. At this point, the document consisted of about a dozen pages, which reflected its authors' preoccupation with precision.

The first seven chapters concern cropping practices. They add requirements to the minimal criteria of the government organic label, just as other demanding private labels may do (Arcuri 2015). The last three chapters spell out the socio-economic commitments, which were previously declarations of principle. One of them, for example, details the trade practices that are conducive to transparency, respect for colleagues, and solidarity. It includes: communicating with members about the volumes for sale and prices practised; planning and sticking to commitments; planning supply movements so as to reduce the distance "from farm to table"; and making long-term trade commitments. Above all, BLO set minimum prices for certain products that would enable farmers to cover their costs, as is done in fair trade networks. Generally speaking, the criteria are precise and measurable wherever possible: "Relations between BLO and its trade partners will have to be part of long-term partnerships, i.e., a threeyear multi-annual contract". When transparency is tackled, and the transparency requirement is essential for the life of the collective, the text stipulates, “...the farmer must be transparent with her/his colleagues about the volumes for sale and prices practised by using the online quoting tool". That is just one example.

These freely developed standards express the BLO members' project. Given their dissatisfaction with the public standards governing their activity, the farmers asserted the type of organic agriculture that they wanted to promote together. Each standard was adopted by a consensus during the general meetings of the BLO. In addition, a committee tasked with making regular proposals for revisions was set up. We counted some ten changes made in the specifications in 2017 and 2019 based on feedback about experiences and agronomic advances. These amendments, which have usually been in the direction of stricter requirements, are always discussed in relation to their compatibility with the collective project. To foster dialogue 
and the involvement of everyone, the monitoring committee is changed every year by random selection.

\section{The devices that make the rules and project come alive}

This monitoring committee is an example of the devices that BLO's members put in place to produce and give life to a common understanding of the rules and project. Other administrative and technical devices can be similarly described.

The first device - one that is usual in the case of standards - was the inspection device. In 2015 the farmers approved the institution of external inspections by a certifying body to complement official standards inspections. This made it possible to give the (now officially registered) "Bio Loire Océan" trademark the attributes of a private standard, that is to say, of a trademark associated with publicised, verified criteria. This choice was discussed at great length, with certain farmers echoing the codification and certification risks raised in the introduction to this article. However, a consensus in its favour was finally reached, as expressed through a vote in a general assembly meeting.

Three market intermediation devices set up by BLO play, as well, a major role for this association, which wants to establish trade relations that are fully in line with its project. The collective did indeed gradually create instruments to this end around i) a supply planning device where each farmer commits to production volumes for the coming months, ii) an online supply tool where each farmer states every week what produce s/he offers at what price and iii) a centralised invoicing scheme that allows customers to pay BLO regardless of the farmers who supplied the produce. Thanks to the last two devices, each member of BLO remains free to conduct her/his own market activity, including that done within BLO. Unlike what traditionally happens in a cooperative, each farmer agrees on the volumes and prices with the buyers, rather than having the prices set by the cooperative's management. BLO's employees do the centralised invoicing in order to make things easier for the buyers, but each farmer remains in 
control of her/his market activity. Yet, with these two devices, each member can at any moment see all of the trading done by her/his colleagues in the association. It is thus possible to check that no-one in the organisation is strategically lowering the prices momentarily in order to get rid of an overabundant harvest. In addition, when a customer such as Biocoop feels that the prices of BLO's members are too high, it can initiate negotiations and put forward its arguments. These negotiations are transparent and visible to all growers and the BLO administrative staff. This very innovative intermediation device (BLINDED FOR PEER REVIEW) enables the project to run in line with the requirements expressed in the charter and specifications, i.e., transparency, trust, and solidarity.

\section{Negotiations and learning in the crafting of rules and projects}

The collective project was thus gradually fine-tuned in texts and operationalised in practices through the mediation of technical and managerial devices. The rules and standards have often been described as vectors of harmonisation and stabilisation. Indeed, this is not entirely false. However, it is also important to observe that rules have social lives - they evolve over time based on how they are used and the contexts within which they circulate (Ostrom et al. 1994; Loconto and Demortain 2017).

The case of BLO offers insights into these dynamics of negotiation and collective learning. For instance, in 2015, during the first farm inspections that followed the drafting of standards specific to BLO, the validation of a common core of non-negotiable principles opened up room for flexibility and tolerance on other points. The annual revision of the specifications that was carried out to gain feedback from the actors' experiences was a moment of negotiation as well. In addition, straying from the rules also occurred during the life of BLO. Certain farmers could ask their colleagues or the management for derogations on certain rules in transition phases or 
during trying circumstances. All these adaptations and arrangements are an aspect of the connection between rule and action.

These negotiations are part of the lives of rules and attest to their catalytic effect on generating collective learning. A good example of these learning processes is given by the story of the online planning tool already mentioned. In the early 2000s the farmers' offers were centralised at one hub farm (which changed each month) responsible for shipping the produce to Biocoop. In practice, the hub farmer faxed a request to all her/his colleagues to ask what products were available and the proposed prices. S/he recorded all the supply figures and quotes in one document and then sent it on in a single fax to Biocoop. Biocoop then sent back its order, which the hub farmer forwarded to everyone. The alarm was sounded in 2007 by both the farmers and the buyers. The existing system was proving increasingly cumbersome in practice, especially given the rising volumes being traded. "The faxes, which were refaxed and refaxed again, became illegible," (interview with a vegetable farmer, 2016). The system was indeed coming to the end of the road, but several members of the management explained that this cumbersome work had also reinforced their collective. "We did that for two or three years, until everyone had his turn and was truly fed up with it... However, all that work together had brought us closer and we said that we could go farther" (interview with a vegetable farmer and BLO member, 2016). A commission was thus set up to think about the solutions that the association could provide. That culminated in the "online supply tool", which thenceforward became a key coordinating device both within BLO and with its customers.

In sum, the farmers learned to work together, developed their own tools and used these tools whilst being mindful of following their project's orientations. This operationalisation of their project was by no means clear at the beginning of their collaboration. A singular and original project for organic production and commercial intermediation was thus confirmed. In the next section, we discuss the significance of these empirical insights for our research question. We 
shall show how this rule-generating activity contributes to the preservation of the alterity of organic farming.

\section{When standardisation reasserts an alternative project}

The literature review presented in the introduction to this article revealed that a lot of existing research established a link between setting standards and conventionalisation. Yet, BLO seems to have escaped this slippery slope. On the contrary, the work done by BLO's members on the association's rules appears to have asserted their project's alterity.

\section{Standardisation that does not weaken the requirements of organic agriculture}

Our case study shows first of all that a weakening of the rules is not inevitable. In the case of BLO, the yearly re-assessment and changes in the rules tend to reinforce the differences between BLO farmers' practices and conventional agriculture. The softening of requirements in the EU organic regulations has led BLO's members to strengthen their own (e.g., regarding off-ground cultivation). Similarly, whereas the principles of farm workers' labour rights were first included rather vaguely in BLO's rules, drafting the specifications enabled the association to refine and bolster them. The least zealous advocates of such rights amongst the association's members became aware of the importance of such issues and fell in step with the others. The same goes for the rules concerning the development of short supply chains and the farmers' involvement in societal matters.

We admit that it is more complicated to codify social behaviours than to prohibit inputs. However, the example of BLO shows that rules can be devised, written and formalised to support such goals. "Participating at least once a year in actions to meet with citizens (visiting 
schools, holding farm open-houses, etc.)" and "spending at least one day welcoming new workers (even seasonal ones)" are examples of the criteria included in the BLO standards.

Moreover, research has underlined the fact that it is difficult in practice to maintain the complexity of certain agro-ecological principles when precise, verifiable rules must be written (Rosset and Altieri 1997; Seppänen and Helenius 2004). Whilst we do see this in our case, we also observe the virtues of establishing such rules collectively. When actors are required to reach consensus on explicit wording, they begin to take into account the implications of future rule enforcement. This in turn opens up a space for dialogue where each actor takes the time to consider the specific constraints on and aspirations for their farms. Debate, deliberations, and negotiations then become opportunities to affirm the project guiding the collective action. For BLO's farmers, this space enabled them to refine their visions of the profession and to position themselves in favour of stricter requirements than those of the EU regulation. In turn, they asserted their project through the rules that they wanted to put into place.

As Ostrom has demonstrated, rules determined according to a self-regulating principle "are often tailored to the specific characteristics of the CPR [common-pool resource]. Rules imposed by external authorities may fail to draw on knowledge of the time and place characteristics of a specific CPR" (Ostrom et al. 1994, p. 304). The case of BLO confirms the need to collectively develop rules that are adapted to the local context, but we also see how powerful rules are when they are based on a collective project.

\section{The affirmation of one's own rules manifesting one's independence}

The case study further shows that it is vitally important to take account of the governance of collective action in order to judge how the production of standards influences the alterity of organic agriculture trajectories. In the BLO case, the rules that are produced change with the work of the actors that use them (i.e., the member market gardeners and orchardists). This is not the case for most public and private organic agriculture standards, which are drawn up to 
provide a framework for all of the farmers producing in a given geographic area. For the BLO collective, the farmers themselves continuously discuss and define the rules that frame their organisational interactions and make their collective action original.

The members' control over the collective project stems notably from the roles of the managerial and operational bodies, and from specific devices. Changes in the rules (e.g., standards' specifications) are always debated by the Board of Directors and in the general assembly (and it should be added that participation in the observed general assembly meetings was close to 75 per cent of the members, on average). No important decision is taken without prior discussion during these meetings. When a choice warrants thorough scrutiny, a working group composed of volunteers from the association's membership is set up. Generally speaking, the decisions tend to be taken by a consensus rather than a majority vote.

"If someone opposes a proposition, it is usually adapted to allow for that. We vote by a show of hands, but that often culminates in a quasi-unanimity, after discussion. We strive for a consensus before voting, so that no-one feels frustrated, to ensure that her/his opinion was clearly heard" (interview with a vegetable farmer and BLO board member, 2016).

For the farmers, the production of written rules is part and parcel of the will to assert a project whilst avoiding the risks of this project's escaping their control or being neutered. After that, the farmers are again the ones who make the written rules come alive. They have consciously designed their own devices to accomplish this, i.e., the marketing tool, planning tool, pricesetting tool, etc. This autonomy is a consistent value defended by the leaders of BLO. For example, during a general assembly meeting of 2014 one member of the board expressed the expected advantages of building a private standard:

“...having specifications that are faithful to our project and belong to us, combined with our Bio Loire Océan brand; being able to communicate about our practices and products; 
managing changes to our specifications ourselves; possibly allowing us to get access to new markets".

This excerpt is interesting in that it combines two different arguments. The first argument $-\mathrm{a}$ relatively conventional marketing argument - sees the creation of a private label as an opportunity to make products of superior quality visible to consumers who are looking for it. However, this argument is far from the only one. The stakes riding on giving themselves specific rules and thus of asserting a singular collective project is even more important in the farmers' opinions. Then - still during the same meeting - an argument in terms of learning is put forward:

"This will entail lengthy, likely somewhat fastidious, but interesting work to take stock of everyone's practices and get them to advance; to think about the techniques, their impacts, and their limits; and to set criteria of progress and improvement".

Here the advocates of the BLO project express the idea that writing the rules is indispensable for reflective discussion about their project. It enables them to go beyond the development of somewhat vague, general ideas. This drafting work fosters the BLO collective to reflect on the collective action that it is carrying out and upon which it is founded.

These last elements finally bring us to understanding why the establishment of rules can be considered to be the vector of an alternative collective project. Here "alterity" must be understood in relation to the debate about conventionalisation. BLO's standards assert a stricter form of organic agriculture that is faithful to its historical project as expressed in IFOAM's principles. However, first and foremost, "alterity" is also understood in the BLO collective's will for autonomy vis-à-vis the organic agriculture sector's rules and official standards. By 
giving themselves specific standards, BLO's farmers have asserted a project that is of their own making and with which they identify.

\section{Conclusion}

To date, research into the roles of standards in organic agriculture has focused on what organises the relations between organisations in the sector. This literature concentrates on public and professional standards and barely examines the rules that organise the work within the producers' organisation (for an exception, see: Guptill and Welsh 2008). This is a questionable narrow perspective. The history of organic farming in France and across Southern Europe, tells us that producers' organisations were and remain important players in shaping the sector (Arcuri 2015; Leroux 2011; Dufeu and Le Velly 2016). In this article we focused, in line with Guptil and Welsh (2008), on the rules that organise work within the farmers' organisations or with their direct partners. To that end, we drew upon the case of a farmers' collective that established its own formal rules. By using an original conceptual framework centred on the roles of projects and rules in producing collective action, we examined the relations between establishing rules and the alterity of organic agriculture from a new angle.

In contrast to other studies, we conclude that standardisation devices can sometimes maintain alterity and help actors to avoiding conventionalisation. Tracing the writing of the BLO charter, specifications and standards since 2005 enabled us to determine exactly how the continuous establishment of rules could be a way to assert an alternative collective project. Through their work on rules, the BLO farmers gave life to a demanding organic agriculture project whilst manifesting relative independence from the sector's official rules. The drafting of precise, 
binding standards, compliance with which could then be checked, enabled the actors to participate in a conscious struggle against conventionalisation.

This study suggests that there is thus a need to look more carefully at the private labels stemming from farmers' collectives and how they work within organizations. Currently, private, "third-party" sustainability standards dominate in agri-food systems Their dominance has been credited to the "independence" of standards-setters from implementers, which has been hailed as a guarantee of scientific impartiality (Bennett 2017; Loconto 2017). However, our case shows that standards devised by the farmers themselves are not necessarily sources of laxer sustainability requirements. Whilst this latter risk remains, we find that there is the possibility for them to stay true to organic principles if there is a collective project that drives the writing and implementing of the rules. Hatanaka (2010) reveals quite clearly the tendency for "independent" private standards to turn farmers into simple "standards takers". This article 
challenges this idea by showing that rules within projects can indeed stimulate collective action, turning farmers into "standards makers" in their own right.

\section{References}

Data available on request from the authors

Allen, P. and M. Kovach (2000) The capitalist composition of organic: The potential of markets in fulfilling the promise of organic agriculture. Agriculture and Human Values 17 (3) pp. 221-232

Arcuri, A. (2015) The transformation of organic regulation: The ambiguous effects of publicization. Regulation \& Governance 9 (2) pp. 144-159

Bennett, E.A. (2017) Who governs socially-oriented voluntary sustainability standards? Not the producers of certified products. World Development 91 pp. 53-69

Boutinet, J.-P. (2012) Anthropologie du projet (2nd edition) (Paris: PUF)

Brunsson, N., Rasche, A. and D. Seidl (2012). The dynamics of standardisation: Three perspectives on standards in organisation studies. Organisation Studies 33 pp. 613-632.

Busch, L. (2011) Standards: Recipes for reality (Cambridge: MIT Press)

Campbell, H. and C. Rosin (2011) After the 'organic industrial complex': An ontological expedition through commercial organic agriculture in New Zealand. Journal of Rural Studies 27 (4) pp. 350-361

Crozier, M. and E. Friedberg (1980) Actors and Systems: The Politics of Collective Action (Chicago: Chicago University Press)

Darnhofer, I., T. Lindenthal, R. Bartel-Kratochvil and W. Zollitsch (2010) Conventionalisation of organic farming practices: From structural criteria towards an assessment based on organic principles. A review. Agronomy for Sustainable Development 30 (1) pp. 67-81

Darnhofer, I. (2020) Farming from a process-relational perspective: Making openings for change visible. Sociologia Ruralis, accepted article

Daviron, B. and I. Vagneron (2011) From commoditisation to de-commoditisation ... and back again: Discussing the role of sustainability standards for agricultural products. Development Policy Review 29 (1) pp. 91-113

Desreumaux, A. and J.-P. Bréchet (2018) Repenser l'entreprise une théorie de l'entreprise fondée sur le projet (Villeneuve D'Ascq: Presses Universitaires du Septentrion)

Dewey, J. (1929) The Quest for Certainty: A Study of the Relation of Knowledge and Action (Oxford: Minton, Balch)

Dolan, C.S. (2010) Virtual moralities: The mainstreaming of fairtrade in Kenyan tea fields. Geoforum 41 (1) pp. 33-43

Dubuisson-Quellier, S. and C. Lamine (2008) Consumer involvement in fair trade and local food systems: Delegation and empowerment regimes. GeoJournal 73 (1) pp. 55-65

Dufeu, I. and R. Le Velly (2016) Quelle régulation pour les filières biologiques? Innovations Agronomiques 51 pp. 67-76 
DuPuis, E.M. and S. Gillon (2009) Alternative modes of governance: Organic as civic engagement. Agriculture and Human Values 26 (1-2) pp. 43-56

Eden, S., C. Bear and G. Walker (2008) Mucky carrots and other proxies: Problematising the knowledge-fix for sustainable and ethical consumption. Geoforum 39 (2) pp. 1044-1057

Emirbayer, M. and A. Mische (1998) What is agency? American Journal of Sociology 103 (4) pp. $962-1023$

Fouilleux, E. and A. Loconto (2017) Voluntary standards, certification, and accreditation in the global organic agriculture field: A tripartite model of techno-politics. Agriculture and Human Values 34 (1) pp. 1-14

Friedberg, E. (1997) Local Orders: Dynamics of Organized Action (Greenwich: Jai Press)

Getz, C. and A. Shreck (2006) What organic and fair trade labels do not tell us: Towards a place-based understanding of certification. International Journal of Consumer Studies 30 (5) pp. 490-501

Gibbon, P. (2008) An analysis of standards-based regulation in the EU organic sector, 19912007. Journal of Agrarian Change 8 (4) pp. 553-582

Gómez Tovar, L., L. Martin, M.A. Gómez Cruz and T. Mutersbaugh (2005) Certified organic agriculture in Mexico: Market connections and certification practices in large and small producers. Journal of Rural Studies 21 (4) pp. 461-474

Goodman, D., M. DuPuis and M. Goodman (2012) Alternative food networks. Knowledge, practice and politics (London: Routledge)

Guptill, A. and R. Welsh (2008) Is relationship marketing an alternative to the corporatization of organics? A case study of OFARM. Pp. 55-78 in T. A. Lyson, G. W. Stevenson and R. Welsh eds., Food and the Mid-level Farm: Renewing an Agriculture of the Middle (Cambridge, MA: MIT Press)

Guthman, J. (1998) Regulating meaning, appropriating nature: The codification of California organic agriculture. Antipode 30 (2) pp. 135-154

Guthman, J. (2004a) Agrarian Dreams: The Paradox of Organic Farming in California (Berkeley: University of California Press)

Guthman, J. (2004b) The trouble with 'organic lite' in California: A rejoinder to the 'conventionalisation' debate. Sociologia Ruralis 44 (3) pp. 301-316

Hatanaka, M. (2010) Certification, partnership, and morality in an organic shrimp network: Rethinking transnational alternative agrifood networks. World Development 38 (5) pp. 706-716

Hatanaka, M. (2014) Mcsustainability and mcjustice: Certification, alternative food and agriculture, and social change. Sustainability 6 (11) p. 8092

Jaffee, D. (2007) Brewing Justice: Fair Trade Coffee, Sustainability and Survival (Berkeley: University of California Press)

Jaffee, D. and P.H. Howard (2010) Corporate cooptation of organic and fair trade standards. Agriculture and Human Values 27 (4) pp. 387-399

Joas, H. (1996) The creativity of action (Cambridge: Polity press)

Leroux, B. (2011) Les agriculteurs biologiques et l'alternative: Contribution à une anthropologie politique d'un monde paysan en devenir. Paris: EHESS. 
Le Velly, R. (2019) Allowing for the projective dimension of agency in analysing alternative food networks. Sociologia Ruralis 59 (1) pp. 2-22

Lehtimäki, T. (2019) Making a difference. Constructing relations between organic and conventional agriculture in Finland in the emergence of organic agriculture. Sociologia Ruralis 59 (1) pp. 113-136

Lamine, C. and J. Rouchier (2016) D'une charte l'autre. Revue de la Régulation [en ligne], 20(2).

Lockie, S. and D. Halpin (2005) The 'conventionalisation' thesis reconsidered: Structural and ideological transformation of Australian organic agriculture. Sociologia Ruralis 45 (4) pp. 284-307

Loconto, A. and E. Fouilleux (2014) Politics of Private Regulation: ISEAL and the shaping of transnational sustainability governance. Regulation \& Governance 8(2) pp. 166-185

Loconto, A. (2017) Models of Assurance: Diversity and Standardization of Modes of Intermediation. The Annals of the American Academy of Political and Social Science 670(1) pp. 1-21

Loconto, A. M. and D. Demortain (2017) Standardization as Spaces of Diversity. Engaging Science, Technology, and Society 3 pp. 382-392

Mutersbaugh, T. (2005) Fighting standards with standards: Harmonization, rents, and social accountability in certified agrofood networks. Environment and Planning A 37 (11) pp. 2033-2051

Nelson, E., L. Gómez Tovar, R. Schwentesius Rindermann and M.Á. Gómez Cruz (2010) Participatory organic certification in Mexico: An alternative approach to maintaining the integrity of the organic label. Agriculture and Human Values 27 (2) pp. 227-237

Olson, M. (1965) The logic of collective action. Public goods and the theory of groups (Cambridge MA: Cambridge University Press)

Ostrom, E. (1990) Governing the commons. The evolution of institutions for collective action (Cambridge MA: Cambridge University Press)

Ostrom, E., R. Gardner and J. Walker (1994) Rules, games and common-pool resources (Ann Arbor: The University of Michigan Press)

Padel, S., H. Röcklinsberg and O. Schmid (2009) The implementation of organic principles and values in the European regulation for organic food. Food Policy 34 (3) pp. 245251

Reynaud, J.-D. (1997) Les règles du jeu. L'action collective et la régulation sociale (3rd edition) (Paris: Armand Colin)

Rosset, P.M. and M.A. Altieri (1997) Agroecology versus input substitution: A fundamental contradiction of sustainable agriculture. Society \& Natural Resources 10 (3) pp. 283295

Seppänen, L. and J. Helenius (2004) Do inspection practices in organic agriculture serve organic values? A case study from Finland. Agriculture and Human Values 21 (1) pp. $1-13$

Seufert, V., Ramankutty, N. and T. Mayerhofer (2017) What is this thing called organic? How organic farming is codified in regulations. Food Policy 68 pp. 10-20 
Stock, P., V., M. Carolan and C. Rosin eds. (2015) Food Utopias. Reimagining Citizenship, Ethics and Community (London: Routledge)

Strauss, A., L. Schatzman, R. Bucher, D. Ehrlich and M. Sabshin (1963) The hospital and its negotiated order. Pp. 147-169 in E. Freidson ed., The Hospital in Modern Society (New York: The Free Press)

Teil, G. (2014) Is organic farming unsustainable? Analysis of the debate about the conventionalisation of the organic label. Pp. 325-344 in S. Bellon and S. Penvern eds., Organic Farming, Prototype for Sustainable Agricultures (Dordrecht: Springer Netherlands)

Timmermans, S., and S. Epstein (2010) A world of standards but not a standard world: Toward a sociology of standards and standardisation. Annual Review of Sociology 36 pp. 69 89

Vogt, C.R., L. Kilcher and H. Schmidt (2005) Are standards and regulations of organic farming moving away from small farmers' knowledge? Journal of Sustainable Agriculture 26 (1) pp. $5-26$

Vos, T. (2000) Visions of the middle landscape: Organic farming and the politics of nature. Agriculture and Human Values 17 (3) pp. 245-256

Wright, E.O. (2010) Envisioning Real Utopias (London: Verso) 